\title{
Dispute Resolution on Unauthorized Trading in Indian Securities Market: A Case Study Approach*
}

\author{
Bezawada Brahmaiah \\ ICFAI Business School, IFHE, Hyderabad, India \\ Email: brahmaiahb@yahoo.com
}

How to cite this paper: Brahmaiah, B. (2017) Dispute Resolution on Unauthorized Trading in Indian Securities Market: A Case Study Approach. Theoretical Economics Letters, 7, 1814-1820. https://doi.org/10.4236/tel.2017.76123

Received: September 18, 2017

Accepted: October 27, 2017

Published: October 30, 2017

Copyright $\odot 2017$ by author and Scientific Research Publishing Inc. This work is licensed under the Creative Commons Attribution International License (CC BY 4.0).

http://creativecommons.org/licenses/by/4.0/

\section{(c) (i) Open Access}

\begin{abstract}
The paper examines the regulatory compliances of the trading rules and regulations of the Stock Exchanges by trading members while serving its clients in the securities market in India. The paper opted for a case study approach to study the unauthorised trading practices of trading members on Indian Stock Exchange system and identified the nature and complexity of securities market's misuses and abuses. The paper identifies how trading members are violating and avoiding the compliances of trading regulations of the Stock Exchange. The paper provides empirical evidences and insights how the trading members were indulging in unauthorised trades and recovering the losses on account of unauthorised trades from the respective clients. The paper finds that these practices are not only violation of trading rules of the Stock Exchange but also unfair and unethical trading practices. The limitation in a case study approach, the research findings and results may lack generalizability. Hence, researchers are encouraged to study results in other countries. This paper provides inputs for the development of appropriate regulatory framework for prevention of unauthorised trading in Indian securities market, curtails capital market abuses and enables the investor protection. The findings and results provide critical perspectives on regulatory challenges and encourage the regulatory authorities to issue relevant guidelines to stock brokers to prevent executing unauthorised trades for clients. These guidelines will certainly prevent the menace of unauthorised trades and curtail capital market abuses and enhance investor protection.
\end{abstract}

\section{Keywords}

Arbitration, Unauthorised Trades, Stock Exchanges, Trading Member, Client

*Names of client (Applicant), trading member, (Respondent), and Exchange were disguised to preserve confidentiality. The facts and circumstances were remaining same to maintain originality of the case matter. It was based on an arbitration matter. The Arbitration mechanism of the Stock Exchange is framed under the Arbitration and Conciliation Act, 1996. 


\section{Introduction}

This case is a reference matter for the arbitration which was referred under the rules, bye laws and regulations of the Stock Exchange. This is an appeal matter with the Stock Exchange against the Order passed by the Member, Investors Grievances Redressal Panel (IGRP), the Stock Exchange with regard to a dispute on unauthorized trades between a client and trading member. The Applicant, Andhra Stock Broking Ltd. is a trading member and stock broker on the Stock Exchange (SE), the leading Stock Exchange of India having registered office in Mumbai and Hyderabad, India. The Respondent is a client with the Applicant, having registered with it for carrying out securities transactions on the Stock Exchange. The Applicant, Andhra Stock Broking Ltd. filed an arbitration application requesting for vacation of the frozen amount of INR 1.0 million from the Stock Exchange (SE). Applicant challenged the Order on the grounds that the award was the result of the pre-mediated conclusion, ignorance of judicial principles, and misreading of the provisions of the Stock Exchange. Accordingly, the Arbitration proceedings were initiated. They presented their arguments, and pleadings in addition to the written statements. Applicant submits that the Respondent raised a dispute and claim, relating to the transactions carried out in her account. The complaint was taken up by the Investor Grievances Redressal Panel (IGRP) of the Stock Exchange for resolution through conciliation proceedings [1]. Applicant contended that such a unilateral declaration in a conciliation proceeding was ultra-vires the law i.e., the Arbitration and Reconciliation Act, 1996 and principles of equity and natural justice. The conciliation did not result in resolution of the dispute by consent of the parties. The parties could not reach a settlement of the disputes amicably through the conciliation process. However, member, IGRP passed an order that INR 1.0 million (Rupees one million only), was admissible as against the claim of INR 10.00 million (Rupees ten million only). The amount of INR 1.00 million was neither mooted nor proposed by either of the parties participating in the conciliation. Conciliator himself decided that INR 1.0 million was the admissible claim. Sub-Section 3 of Section. 73, of the Arbitration and Conciliation Act, 1996 [2] clearly lays down the legal position that what shall be final and binding on the parties in a conciliation proceeding is the settlement agreement signed by the parties. Applicant was invited for conciliation but was handed a punishment, unheard and without being afforded an opportunity to defend itself before a competent forum following the due process of law. The dispute raised by the Respondent before the IGRP is still Res Integra, an untouched matter, untouched by dictum or decision of any authority in due exercise of its adjudicatory powers, whether judicial or quasi judicial. Complainant has not proved her case.

\section{Case Description}

Applicant objected the order passed by the Conciliator and such a decision is not germane to the process of conciliation as, in its very nature, conciliation is nei- 
ther judicial nor even quasi judicial. The relief claimed herein is the lifting of the blockage over its fund which is oppressive and arbitrary and a punishment against the universally celebrated doctrine Audi alteram partem, that nobody should be condemned unheard without giving him a fair chance to defend before a competent forum, having the power under the law of the land to dispense justice by a binding order, consistently with the due legal processes established by law. There is no finding at all that the Applicant is liable to pay the amount declared admissible by the Conciliator to the complainant. There is no provision even in the Securities and Exchange Board of India (SEBI) [3] circular referred that the decision of the Conciliator is conclusive as against the parties and could be enforced without complying with the due process of law, but provides for final resolution by adjudication in formal arbitration. The Respondent is a party to an arbitration agreement with the Applicant and if she has a dispute or a claim pertaining to any matter which is subject to the arbitration agreement. In terms of the SEBI Regulations, the Respondent is obliged to seek resolution of any disputes, differences or claims pertaining to any transactions carried out on the trading platform of the Stock Exchange through arbitration process. The Respondent has not established any case against the Applicant so far in any manner by following the procedure according to the law of land. The restraint imposed on the Applicant against the use of its funds is therefore, unjust, unlawful and ought to be vacated.

Applicant submits that written statement submitted by the Respondent is vague, misleading and incomplete and all the trades were duly executed with the consent of the Respondent and SMS messages, phone calls, and ECN logs regarding trading transactions were sent to her well on time.

Applicant states that Respondent traded in Future and Options (F \& O) segment and was well aware of all her trades. Therefore all allegations are after thought and not to be relied upon in the absence of any evidence to that effect. Applicant states that Respondent is not speaking truth and making different statements of claim. Applicant submits that Respondent was registered as a client through its sub broker and all communication and other correspondence related to orders placement were carried out between the Respondent and sub broker through their personal mobile phones and the sub broker did not maintain any records of order placement, hence there was no proof and evidence available with the sub broker of the Applicant. Applicant prays that the vacation of the blockage amount of INR 1.0 million and the amount is to be released to the Applicant and (ii) such other order in favour of the Applicant as the Hon'ble Tribunal may deem fit and proper.

Respondent, Ms Adi Lakshmi, clarified that she had incurred a loss of INR 10.00 million (Rupees ten million) due to the unauthorized trading carried out in F \& O segment by the Applicant, Andhra Stock Broking Ltd. Applicant transferred funds from her cash market account to $\mathrm{F} \& \mathrm{O}$ account without her prior consent or permission. She reiterated that none of the trades in F \& O account was carried out with her prior approval or instructions. She was a layperson in 
the trading field. According to the Respondent, the intentions of the sub broker were misleading and misguiding her. Respondent clarified that about 80 per cent of the transactions were done offline and unauthorised. She did receive digital contracts on daily basis and when she inquired about it, she was informed by the sub broker that it was just a formality and compliance of regulations of the Stock Exchange and SEBI and she was advised to ignore them. She only obliged to whatever the sub broker told her. The main bone of contention was that the transactions were done without her consent in F \& O segment. Since she was not aware of as to how to continue with the transactions and she was forced to approach the sub broker to continue her transactions. By October 2014, she warned the sub broker to stop trading in her account and return her equity holdings lying with the Applicant as on that date and the sub broker told her that all her holdings in cash market were there and there was no need to worry about them. Suddenly, the sub broker had stopped trading in her account and she spoke to sub broker about her positions in F \& O segment. Sub broker reported her that all her positions in F \& O segment were closed out and no need to worry; he would take care of them. Respondent claimed that the sub broker had taken all wrong steps and manipulated from the beginning. She realized and found that she was misled, duped and cheated. During the period, her equity holdings were sold off in the cash market and the pay outs (payments) from these sales were transferred to F \& O segment to meet the MTM and other losses. She had lost nearly INR 10.00 million (rupees ten million only) because of unauthorized trading in her account. Respondent had claimed a loss of INR 10.00 million on account of unauthorised trades carried out by the Applicant. The sub broker did all these business activities without proper information. He had taken all the positions and squared off these positions on his own without her knowledge and instructions. Client protection is more important than anything else for the trading member. Applicant was not bothered about clients' losses but it was interested in daily revenue targets rather than investor's protection.

\section{Discussion and Analysis of Case}

Client was put to a loss of INR.10.00 million as a result of the unauthorised trading in the client's account and client made a claim for the said amount from the trading member.

Member, IGRP concluded that the client neither substantiated nor justified her grounds to produce any documentary evidence for the said loss of INR.10.00 million. Member, IGRP also made a remark that the trading members should ensure that the appropriate confirmed order instructions are to be obtained from the clients before placing orders on the system and shall keep these records and documents for further evidence. However, trading member did not produce any evidence for such order confirmation that the orders were placed by the client for buying or selling the shares. Trades in $\mathrm{F} \& \mathrm{O}$ segment were executed by 
the dealer of the Applicant without proper instructions. Member, IGRP, passed an order directing the trading member to pay INR 1.0 million, which is equal to 10 per cent of the loss incurred and claimed by the client.

It is observed that the Applicant indulged in unauthorised trading in client's account. Respondent did not conduct due diligence of the securities market and blindly believed the sub broker of the Applicant. Respondent traded without understanding the risks and rewards of investment and trading in the securities market. It is observed that the Respondent had never disputed any of the trades in her account during the trading period. Respondent was aware of all the trades and losses in her account. It is concluded that the Respondent committed a mistake by allowing unauthorised trading for about four months in her account. It is observed that the Applicant had followed all its duties and obligations such as sending daily contract notes, margin statements, bills etc., over phone, email and SMSs very meticulously and promptly so that records speak of everything was correct, and proper from the Applicant's side. Respondent was assigned to the sub broker of the Applicant and the sub broker did all these unauthorised trades and incurred the losses on account of these trades. Equity holdings of the Respondent in cash markets were sold by the sub broker and the pay outs (payments) from these sales were transferred to $\mathrm{F} \& \mathrm{O}$ segment to meet the mark to market (MTM) losses and other losses without instructions from the Respondent. Applicant's team destroyed the capital of the Respondent. Respondent provided details of unauthorised trades and losses incurred on these trades and calculated the total loss on account of the unauthorised trades was INR 10.80 million as against the original claim of INR 10.00 million.

The main issue in this matter is whether the disputed trades carried out were unauthorised or not. It is concluded that these trades were considered as unauthorised in spite of being confirmed to the Respondent on post trade bases. These trades were unauthorised because these were not originated from the Respondent i.e., Respondent did not place these orders.

Applicant confessed and confirmed that the sub broker could not maintain any records of order placement, hence there was no proof and evidence of order placement was available with the Applicant. Applicant provided a lot of details and information but could not provide any relevant and authentic proof and evidence that these disputed orders were placed by the Respondent. Trading Member's operations and activities are regulated by the stock exchanges, the Bombay Stock Exchange Ltd. (BSE), National Stock Exchange of India Ltd. (NSE) and Securities and Exchange Board of India (SEBI) in order to protect the interests of the investors. It is clearly and absolutely violation of trading rules of the Stock Exchange by the Applicant. Respondent consented and cooperated for such trades on confirmation without preventing the dealer from indulging in unauthorised trading. Respondent submitted the details of unauthorised trades executed by the Applicant and losses incurred thereon. The total loss on account of the unauthorised trades was INR 10.80 million. Even though, the Respondent 
had full knowledge and complete information of the unauthorised trades, Trading Member is not discharged from the violation of trading rules of the BSE and NSE. It is an assumption of the Applicant that by confirming the unauthorised trades to the client, it has right to pass on the losses on unauthorised trades to the client. As per extant guidelines of Stock Exchanges (BSE and NSE) and SEBI, Client can file an arbitration application with the respective Stock Exchanges with in a period of three years from the date of differences and disputes. The limitation period for filing an arbitration application should be governed by the Limitation Act, 1963.

\section{Conclusions}

It is concluded that these trades were considered as unauthorised in spite of being confirmed to the Respondent on ex post facto i.e., post trade bases. These trades were unauthorised because these were not originated from the Respondent i.e., Respondent did not place these orders. It is concluded that the Applicant and Respondent are equally responsible for the unauthorised trades. Respondent consented, cooperated and collaborated with the Applicant for undertaking unauthorised trades with a motive of making money and the Applicant took advantage of the situation in order to earn brokerage income on unauthorised trades. The defence of Applicant that the Respondent had not raised any objection or complaint about unauthorised trading on receipt of contract notes, bills, SMSs, statement of accounts, could not be a sufficient reason and justification to state that all trades are carried out with the consent of the Respondent. Applicant didn't provide adequate, authentic and proper evidence and proofs that these orders were placed by the Respondent. It is the duty of trading member (Applicant) to preserve and provide enough proof or evidence that the orders for the disputed trades were placed by the Respondent. It is concluded that the said disputed trades were executed by the dealer himself without instructions from the Respondent.

As per the extant rules and regulations of the Stock Exchanges and SEBI, trades have to be executed with the orders or instructions from the client (Respondent) and not on the implied consent and knowledge of the client subsequent to the trades. Applicant had violated the trading rules of Stock Exchange by indulging in unauthorized trading and not in complied with the fair trading practices. Client had suffered a loss of INR.10.80 million as a result of unauthorised trading in her account and the loss would be taken into consideration for this arbitration reference and award. Both the Respondent and Applicant are equally responsible and accountable to the unauthorized trades and losses. In view of this, the loss on this account has to be borne by both of them equally on the principles of equity, fairness and natural justice.

Investor protection is an important ingredient for the growth and development of the securities markets in any country. The regulatory authorities of the securities markets have to identify and appoint arbitrators in the panel not only 
from the legal discipline but also experts from the securities market with strong domain knowledge of stock market operations [4]. The arbitrators have to consider and review not only the legal provisions and issues but also trading regulations, trading practices, and marketing techniques of the trading members to attract investors to the securities market. The arbitrators have to analyse the case matter in scientific and systematic way and pass the right, fair, equitable and speaking award on the principles of equity, fairness and natural justice. As a result of a larger number of complaints filed by the investors relating to unauthorised trades, Securities and Exchange Board of India [5], the regulatory authority of the securities market, issued a circular on prevention unauthorised trading by the stock brokers by insisting on the evidence of placement of orders physical record, or telephone recording, or e-mail from authorised email ID, or record of SMs messages before executing trades for clients and when dispute arises, the burden of proof will be on the trading member to produce the records for the disputed trades.

\section{Recommendations}

In view of the foregoing submissions, and arguments of the parties, and on the bases of arbitrator's observations, findings and conclusions, the following award is passed.

The Order passed by the Member, IGRP is set aside and the Applicant, Andhra Stock Broking Ltd. is directed to pay INR 5.40 million (Rupees five million and four hundred thousand only) with an interest of 18 per cent per annum from the date of this award till the payment to the Respondent. Parties have to bear their own costs.

\section{References}

[1] SEBI (2010) Circular No.CIR/MRD/DSA/29/2010 Issued by the SEBI, Mumbai.

[2] The Arbitration and Conciliation Act. (1996)

[3] SEBI (2012) Rights and Obligations of Stock Brokers, Sub Brokers and Clients Issued by the SEBI, Mumbai.

[4] Brahmaiah, B. (2017) Arbitration on Unauthorized Trades by the Trading Member of the Stock Exchange: An Empirical Study. Theoretical Economics Letters, 7, 1557-1567. https://doi.org/10.4236/tel.2017.76105

[5] SEBI (2017) Prevention of Unauthorised Trading by Stock Brokers, September 26, pp. 1-2. 